and such contemporary names as Adams, Millikan, Russell, Shapley and Otto Struve are likely to be as well remembered in the future. Nearly all the major spectroscopic and astrophysical advances of the past half-century are recorded in the first hundred volumes : the Fabry-Perot interferometer, the Rowland solar wave-length table, the first photographic trigonometrical parallaxes and spectroscopic parallaxes, the 100-in. telescope, the Einstein and the nebular red-shifts, 'nebulium' and super-novæ, to mention only a few. With the completion of the 200-in. telescope after the War, science may look to see its boundaries enlarged yet again in the pages of the Astrophysical Journal.

\section{Temperature Compensation in Instruments}

A PAPER read recently in London by Dr. G. F. Tagg before the Institution of Electrical Engineers has for its theme the fact that one cause of errors in indicating and recording instruments is their use at a temperature other than that at which they were calibrated. Most of the physical properties of materials on which instrument performance depends vary to a greater or less degree with temperature. It is therefore necessary when designing an instrument to reduce to a minimum any errors caused by changes in temperature, and if possible to make them negligibly small. This is done either by adopting a design such that the temperature errors themselves are very small, or by introducing other changes with temperature which will compensate them. An account is given in the paper of the more common methods employed, each method being briefly discussed to indicate the best arrangement for each type of instrument. The instruments considered are ammeters, voltmeters, millivoltmeters, wattmeters and rectifier-operated and thermocouple instruments.

\section{Recent Earthquakes}

DURING the third quarter of 1944, fifty-eight earthquakes and tremors were recorded at Toledo, Spain, while during the same quarter twenty-six strong earthquakes were recorded at the Dominion Observatory, Wellington, New Zealand. The earthquake of October 29 was felt with Scale 5 (modified Mercalli) in the southern parts of North Island and Taumarunui; the shock of November 25 was felt at Karamea with Scale 4 and that of December 24 was felt at Timaru with Scale 3 intensity. The United. States Coast and Geodetic Survey determined the epicentres of several shocks which occurred during the quarter. On October 23 the epicentre was in Ecuador, South America; on December 7 (lat. $33^{\circ} \mathrm{N}$., long. $137^{\circ} \mathrm{E}$.) off Japan ; on December 10 in the New Hebrides Islands and on December 12 in the Aleutian Islands.

\section{The Ray Society}

Ar the annual general meeting of the Ray Society held on March 22, Mr. A. D. Cotton, president of the Linnean Society, was elected a vice-president and Prof. F. Balfour-Browne, Dr. W. S. Bristowe and Dr. John Smart new members of Council. It was announced that Dr. F. E. Zeuner's volume on "The Pleistocene Period" would soon be ready for distribution, and that Dr. Dawes's work on "The Trematode Parasites of British Fishes" was nearly ready for printing. Owing to the increase in costs, Dr. Zeuner's book will form the issue to subscribers for the two years 1942 and 1943 , and it is intended that Dr. Dawes's volume shall be issued for the year 1944.
Other works are in preparation, but no dates can yet be announced for their probable publication.

\section{Oliver Lodge Scholarship}

Is order to commemorate the silver jubilee of the Radio Section of the Institution of Electrical Engineers, the Council of the Institution has founded a research scholarship which is to be called the Oliver Lodge Scholarship. It will have a basic annual value of $£ 250$ and will be tenable for one year, but may be extended for a second year. The Council wishes to encourage scholars to travel and, after approval of a candidate's programme, may make an additional grant for this purpose. The scholar will be required to carry out research in a subject closely allied to radio engineering. Further particulars and nomination forms can be obtained from the Secretary, Institution of Electrical Engineers, Savoy Place, Victoria Embankment, London, W.C.2. The closing date for receiving nominations is May 15 , 1945.

\section{Announcements}

THE following have been elected by the Governing Body to honorary fellowship of the Imperial College of Science and Technology: the Most Hon. the Marquess of Crewe, Mr. C. S. Garland, Mr. Percy Good, Dr. Andrew McCance, the Right Hon. Lord Rayleigh, Prof. J. S. Truscott, Lieut.-General Sir Pierre Van Ryneveld, Prof. W. W. Watts, Prof. A. N. Whitehead and Dr. H. E. Wimperis.

Mr. O. S. Puckue, recently of the Research Department of Messrs. A. C. Cossor, Ltd., has been appointed chief engineer of R. F. Equipment, Ltd., Plantation Road, Amersham, Bucks, with a seat on the board. In particular he will be responsible for research and development.

THE posts of inspector-general of forests to the Government of India and president of the Forest Research Institute and Colleges have been separated. A separate post of president of the Forest Research Institute and Colleges, Dehra Dun, has been created; this post is being filled by Mr. C. E. Simmons. The inspector-general of forests (Sir Herbert Howard), with his office and staff, has been transferred to New Delhi. His address in New Delhi will be "Inspector. General of Forests, Department of Education, Health and Lands, New Delhi", and his telegraphic address will be "Igforest, New Delhi". All correspondence connected with research and education at Dehra Dun should be addressed to the President, Forest Research Institute and Colleges.

Trinity College, Cambridge, has decided to resume in the present year the annual offer of a research studentship which has been suspended since 1941. The studentship is open to graduates of other universities who propose to go to Cambridge as candidates for the degree of Ph.D., provided that on June 1, 1945, they have not commenced residence in the University of Cambridge and are not more than twenty-six years of age. In computing the age of a candidate for this purpose, any days of war service will be deducted from his actual age. Candidates should apply through the principal authority of their university, and applications should reach the Senior Tutor of Trinity College (from whom further particulars may be obtained) before June 1 , 1945. 